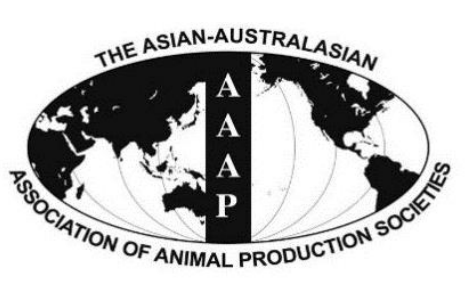

Open Access

Asian Australas. J. Anim. Sci.

Vol. 28, No. 7 : 999-1005 July 2015

http://dx.doi.org/10.5713/ajas.15.0066

pISSN 1011-2367 elSSN 1976-5517

\title{
The Effect of Bacillus-based Feed Additive on Growth Performance, Nutrient Digestibility, Fecal Gas Emission, and Pen Cleanup Characteristics of Growing-finishing Pigs
}

\author{
S. D. Upadhaya, S. C. Kim, R. A. Valientes ${ }^{1}$, and I. H. Kim* \\ Department of Animal Resource and Science, Dankook University, Cheonan 330-714, Korea
}

\begin{abstract}
Bacillus-based feed additive was evaluated for its efficacy on growth performance, nutrient digestibility, fecal gas emission, and the consumption of time and amount of water for cleaning the pen of growing finishing pigs. A total of 120 growing pigs $(23.59 \pm 1.41 \mathrm{~kg})$ were used in a 16 -wk feeding trial. Pigs were randomly distributed into 1 of 2 treatments on the basis of body weight and sex. There were 12 replicate pens per treatment, with 5 pigs ( 3 barrows and 2 gilts) per pen. Dietary treatments were CON which was basal diet, and $\mathrm{T} 1$ which was $\mathrm{CON}+62.5 \mathrm{ppm}$ microbial feed additive that provided $1.47 \times 10^{8} \mathrm{cfu}$ of Bacillus organisms per gram of supplement. During the weeks 0 to 6 , average daily gain $(\mathrm{ADG})$ in $\mathrm{T} 1$ treatment was higher $(\mathrm{p}<0.05)$ than CON, but no improvement in average daily feed intake (ADFI) and feed efficiency (G:F) was noted. During 6 to 16 weeks, no difference ( $p>0.05)$ was noted in growth performance. However, ADG was improved $(\mathrm{p}<0.05)$ and overall ADFI tended $(\mathrm{p}=0.06)$ to improve in T1 compared with CON. At week 6, the co-efficient of apparent total tract digestibility (CATTD) of dry matter (DM) nitrogen $(\mathrm{N})$ was increased $(\mathrm{p}<0.05)$ in T1 compared with CON. Fecal $\mathrm{NH}_{3}$ emission was decreased $(\mathrm{p}<0.05)$ in $\mathrm{T} 1$ compared with $\mathrm{CON}$, at the end of 6th and 15th weeks. The time and water consumed for washing the pens were decreased $(\mathrm{p}<0.05)$ in T1 compared with CON. In conclusion, supplementation with Bacillus-based feed additive could improve the overall growth performances, increase the CATTD of DM and decrease the fecal $\mathrm{NH}_{3}$ content and the time and water consumed in washing the pens for growing-finishing pigs. (Key Words: Bacillus-based Feed Additive, Fecal Gas Emission, Growth Performance, Growing-finishing Pigs, Nutrient Digestibility)
\end{abstract}

\section{INTRODUCTION}

In the intensive animal agriculture system, swine production faces many challenges related to the management of manure. These may include handling and proper storage of manure, odor production, and the accumulation of manure solids in the pen. The production of noxious gases and accumulation of solids in the pen are due to inadequate microbial decomposition of manure (Davis et al., 2008). Mal odor of manure is an acute environmental problem, because they cause emission of noxious gases such as volatile fatty acid, volatile amines

\footnotetext{
* Corresponding Author: I. H. Kim. Tel: +82-41-550-3652, Fax: +82-41-565-2949, E-mail: inhokim@ dankook.ac.kr

${ }^{1}$ DSM Nutritional Products Philippines, Inc., Taguig city 1634, Philippines.
}

Submitted Jan. 26, 2015; Revised Feb. 23, 2015; Accepted Mar. 6, 2015 and sulphur in the livestock facilities (Ushida et al., 2003; Le et al., 2005). These gases have adverse effects in the health of humans and animals, and they also cause negative effects in the environment through eutrophication, nitrification, and acidification of rain (Ferket et al., 2002; Ushida et al., 2003; Le et al., 2005). To solve these problems of odor production and inadequate manure decomposition, different strategies have been utilized such as diet manipulations through the inclusion of crystalline amino acids, fermentable carbohydrates, odor masking compounds and enzymes, and microbial feed additives (Sutton et al., 1999). Inclusion of microbial feed additive was considered to be best suitable, because microbes produce various kind of enzymes which are very effective in manure decomposition (Schreier, 1993) and reduction of malodor (Ushida et al., 2003; Chen et al., 2006; Davis et al., 2008); also, it is a relatively cheap and more convenient 
approach.

Furthermore, microbial feed additive has been promoted as one of the alternatives to improve growth performance in several species (Schrezenmeir and De Vrese, 2001). Dietary supplementation with microbial feed additive has been reported to improve growth performance, nutrient digestibility, and immune status, and they reduce noxious gases produced by excretions of the pigs (Hong et al., 2002; Meng et al., 2010; Lei and Kim, 2014). Various Bacillus spp. were reported to be used as antibiotic alternatives for humans and animals (Hong et al., 2005; Park and Kim, 2014; Jeong and Kim, 2014; Park and Kim, 2015).

Bacillus species-based feed additive used in the present experiment is a heat-stable microbial feed additive that contains organisms, such as B. lichenformis and B. subtilis, which are selected for their ability to improve the decomposition of swine manure. We hypothesized that this feed additive would help optimize performances of the pigs, improve the digestion of manure solids thereby reducing odor and noxious gases levels, make pen cleanup easier, and contribute in reducing environmental pollutants formed from animal manure.

Therefore, the purpose of this work was to evaluate the effects of Bacillus-based feed additive on growth performance, nutrient digestibility, fecal gas emission and microbial shedding, consumption of time and amount of water for cleaning the pens of the growing-finishing pigs and to evaluate the impact of feed additive on reducing environment pollution.

\section{MATERIAL AND METHODS}

The experimental protocols describing the management and care of animals were reviewed and approved by the Animal Care and Use Committee of Dankook University (DK1259).

\section{Source of microbial feed additive}

The microbial feed additive used in the current experiment consisted of Bacillus sps (Micro Source S, DSM Nutritional Products, Basel, Switzerland). The microbial feed additive delivered $1.47 \times 10^{8}$ cfu of Bacillus organisms, comprising 2 strains of $B$. lichenformis and 1 strain of $B$. subtilis per gram of supplement.

\section{Chemical analyses}

The chemical composition of feed was analyzed in triplicate before initiation of the experiment (Table 1). The chemical composition of feed was determined according to AOAC (1995) as follows: moisture (method 930.15), CP (method 990.03), crude fat (method 920.39), crude fiber (method 962.09), crude ash (method 942.05), Ca (method 984.01), P (method 965.17). The amino acid profiles were
Table 1. Feed composition of basal diet (as-fed basis)

\begin{tabular}{|c|c|c|}
\hline Item & 0 to 6 weeks & 6 to16 weeks \\
\hline \multicolumn{3}{|l|}{ Ingredient $(\mathrm{g} / \mathrm{kg})$} \\
\hline Corn & 474 & 566.3 \\
\hline Wheat & 30 & 20 \\
\hline Molasses & 40 & 40 \\
\hline Wheat bran & 30 & - \\
\hline Corn gluten feed & 19 & 20 \\
\hline Soybean meal & 306 & 249 \\
\hline Rapeseed meal & 20 & 20 \\
\hline Corn germ meal & - & 10 \\
\hline Lysine $(80 \%)$ & 1 & 0.6 \\
\hline Methionine (99\%) & 0.4 & - \\
\hline Tallow (liquid) & 50 & 46 \\
\hline Limestone & 9.3 & 12.3 \\
\hline Di-calcium Phosphate & 15.6 & 11.3 \\
\hline Salt & 2 & 2 \\
\hline Vitamin premix $^{1}$ & 1.5 & 1.5 \\
\hline Mineral premix ${ }^{2}$ & 1 & 1 \\
\hline \multicolumn{3}{|c|}{ Calculated composition (\%) } \\
\hline Crude protein & 19.4 & 17.12 \\
\hline Crude fat & 7.63 & 7.41 \\
\hline Crude fiber & 3.1 & 2.76 \\
\hline Crude ash & 5.81 & 5.32 \\
\hline Calcium & 0.8 & 0.8 \\
\hline Total phosphorus & 0.6 & 0.5 \\
\hline Available phosphorus & 0.35 & 0.27 \\
\hline Total lysine & 1.13 & 0.95 \\
\hline Methionine & 0.35 & 0.28 \\
\hline Available methionine & 0.31 & 0.25 \\
\hline \multicolumn{3}{|l|}{ Analyzed composition (\%) } \\
\hline Crude protein & 19.56 & 17.05 \\
\hline Crude fat & 7.6 & 7.32 \\
\hline Crude fiber & 3.23 & 2.79 \\
\hline Crude ash & 5.85 & 5.31 \\
\hline Calcium & 0.81 & 0.8 \\
\hline Total phosphorus & 0.59 & 0.51 \\
\hline Total lysine & 1.18 & 0.98 \\
\hline Methionine & 0.37 & 0.29 \\
\hline
\end{tabular}

${ }^{1}$ Provided per kilogram of complete diet: retinyl acetate, 4,000 IU; cholecalciferol, $880 \mathrm{IU}$; dl- $\alpha$-tocopheryl acetate, $50 \mathrm{IU}$; menadione sodium bisulfate complex, $4.2 \mathrm{mg}$; d-calcium pantothenate, $24.6 \mathrm{mg}$; riboflavin, $8.6 \mathrm{mg}$; and vitamin $\mathrm{B}_{12}, 44 \mu \mathrm{g}$.

${ }^{2}$ Provided per kilogram of complete diet: $\mathrm{Cu}$ (as copper sulfate pentahydrate), $15 \mathrm{mg}$, Fe (as ferrous sulfate heptahydrate), $80 \mathrm{mg}$; Zn (as zinc oxide), $56 \mathrm{mg}$; Mn (as manganese oxide), $73 \mathrm{mg}$; I (as kalium iodate), $0.3 \mathrm{mg}$; Co (as cobalt sulfate pentahydrate), $0.5 \mathrm{mg}$; and $\mathrm{Se}$ (as sodium selenate), $0.4 \mathrm{mg}$.

analyzed by Sykam Amino Acid Analyser (Laserchrom HPLC Laboratories Ltd. Inc., Rochester, UK) after acid hydrolysis for $24 \mathrm{~h}$ in $6 \mathrm{M} \mathrm{HCl}$. Methionine was analyzed after cold performic acid oxidation overnight before hydrolysis. 


\section{Experimental design, animals, housing and diet}

A total of 120 growing pigs ([Yorkshire $\times$ Landrace] $\times$ Duroc) with an average body weight (BW) of $23.6 \pm 1.41 \mathrm{~kg}$ were used in this 16-wk experiment. Pigs were randomly allotted to 2 experimental diets according to their initial BW and sex (2 gilts and 3 barrows/pen; 12 pens/treatment). Dietary treatments were CON which was basal diet and T1 which is CON+62.5 ppm Bacillus-based feed additive. Feed additive was mixed in the ground maize for the basal diet, and all diets were provided as meals that were formulated to meet or exceed NRC (1998) requirements (Table 1). Pigs were housed in an environmentally controlled facility with slatted plastic floor. The target room temperature and humidity were $25^{\circ} \mathrm{C}$ and $60 \%$, respectively. Lights were supplied from 0600 to $2400 \mathrm{~h}$. Each pen was equipped with a self-feeder and nipple drinker to allow ad libitum access to feed and water throughout the experimental period.

\section{Sampling and measurement}

Individual pig's BW was checked at the beginning and at the end of the 6th, 12th, and 16th weeks, and the feed consumption was recorded per pen during the experiment to calculate the average daily gain (ADG), average daily feed intake (ADFI), and gain/feed (G/F) ratio.

Co-efficient of apparent total tract digestibility (CATTD) of dry matter (DM), gross energy, and $\mathrm{N}$ were determined by adding $0.2 \%$ of chromic oxide in the diet as an inert indicator. Pigs were fed with chromium diets one week before the fresh samples of fecal grab were collected from 24 pigs ( 2 pigs per pen), during the 2 separate collection periods at week 6 and week 15. All fecal samples and feed samples were stored in a freezer at $-20^{\circ} \mathrm{C}$ until further analysis. Prior to chemical analysis, the fecal samples were thawed and dried for $72 \mathrm{~h}$ at $70^{\circ} \mathrm{C}$, after which they were grounded to small size to pass through a 1-millimeter screen. All of the feed and fecal samples were analyzed for DM and $\mathrm{N}$, in accordance with the procedures outlined by the AOAC (1995), and then CATTD was calculated. Chromium was analyzed via UV absorption spectrophotometry (Shimadzu, UV-1201, Kyoto, Japan), following the method described by Williams et al. (1962). Nitrogen was measured using a Kjeltec 2300 Analyzer (Foss Tecator AB, Hoeganaes, Sweden). Gross energy was determined using a Parr 6100 oxygen bomb calorimeter (Parr Instrument Co., Moline, IL, USA). The production of manure on dry matter basis per pig per day was calculated using the formula ([1-DM digestibility) $\times$ ADFI].

For the analysis of the fecal $\mathrm{NH}_{3}$, total mercaptans, volatile fatty acid (VFA), and $\mathrm{H}_{2} \mathrm{~S}$, the fresh feces were collected from 2 pigs in each pen at the end of 6th and 15th weeks. The total sampled feces was then thawed and homogenized. Then, the stock feces $(300 \mathrm{~g})$ were stored in
2.6-L plastic boxes with a small hole in the middle of one side that was sealed with adhesive plaster. The samples were allowed to ferment for $1 \mathrm{~d}$ at room temperature $\left(25^{\circ} \mathrm{C}\right)$, and $100 \mathrm{ml}$ of the headspace air was sampled from approximately $2.0 \mathrm{~cm}$ above the fecal sample. After the collection, box was re-sealed with adhesive plaster to measure the fecal noxious content at d 3, d 5, and d 7, as aforementioned. Prior to the measurement, the fecal samples were manually shaken for approximately $30 \mathrm{~s}$ to disrupt any crust formation on the surface of the fecal sample and to homogenize the samples. Concentrations of $\mathrm{NH}_{3}, \mathrm{H}_{2} \mathrm{~S}$, and total mercaptans were measured within the scopes of 5.0 to $100.0 \mathrm{ppm}$ (No. 3La, detector tube; Gastec Corp. Kanagawa, Japan) and 2.0 to $20.0 \mathrm{ppm}$ (4LK, detector tube; Gastec Corp., Japan). The fecal VFA concentration was determined according to the method mentioned by Erwin et al. (1961). The VFA concentration in the supernatant liquid was determined using a gas chromatograph (VARIAN, CP-3800, San Diego, CA, USA).

For fecal microbial analysis, fecal samples were collected by massaging the rectums of 2 pigs from each pen, at $\mathrm{d} 21$ and $\mathrm{d} 42$. The samples were then pooled and placed on ice for transportation to the lab. One gram of the composite fecal sample from each pen was diluted with 9 $\mathrm{mL}$ of $1 \%$ peptone broth (Becton, Dickinson and Co., Franklin Lakes, NJ, USA), and it was homogenized. Viable counts of bacteria in the fecal samples were then conducted by plating serial 10 -fold dilutions (in $1 \%$ peptone solution) onto MacConkey agar plates (Difco Laboratories, Detroit, MI, USA) and lactobacilli medium III agar plates (Medium 638, DSMZ, Braunschweig, Germany) to isolate the E. coli and Lactobacillus, respectively. The MacConkey agar plates were incubated for $24 \mathrm{~h}$ at $37^{\circ} \mathrm{C}$, and the lactobacilli medium III agar plates were incubated for $48 \mathrm{~h}$ at $39^{\circ} \mathrm{C}$, under anaerobic conditions. The E. coli and Lactobacillus colonies were counted immediately after removal from the incubator.

At the end of 6 and 16 weeks, all pens were washed one at a time, and the water and time consumptions were recorded. The time consumption was checked by washing the pens with a water gun using 10 liters of water from a bucket. The result was 90 seconds (s)/ 10 liters (L) $=9 \mathrm{~s} / 1 \mathrm{~L}$. Then, the washing time consumption of each pen was recorded using the same water gun. The time was recorded by using a stopwatch set to zero before washing began in each pen. The formula is water consumption $(\mathrm{L})=$ washing time $(\mathrm{s}) / 9$.

\section{Statistical analysis}

All data were subjected to the statistical analysis as a randomized complete block design using the general linear model procedures of SAS (SAS Inst. Inc., Cary, NC, USA), 
Table 2. Effect of Bacillus-based feed additive on the growth performance in growing-finishing pigs

\begin{tabular}{lcccc}
\hline Item & $\mathrm{CON}^{1}$ & $\mathrm{~T}^{1}$ & $\mathrm{SE}$ & $\mathrm{p}$-value \\
\hline Initial BW (kg) & 23.60 & 23.58 & 0.03 & 0.67 \\
Final BW (kg) & $111.51^{\mathrm{b}}$ & $114.63^{\mathrm{a}}$ & 0.97 & 0.04 \\
Growing phase (0 to 6 wk) & & & \\
ADG (g) & $675.2^{\mathrm{b}}$ & $710.3^{\mathrm{a}}$ & 10.6 & 0.04 \\
ADFI (g) & $1,639.7$ & $1,668.2$ & 12.3 & 0.13 \\
G/F & 0.412 & 0.426 & 0.007 & 0.20 \\
Finishing phase (6 to 16 wk) & & & \\
ADG (g) & 850.6 & 874.5 & 13.6 & 0.24 \\
ADFI (g) & $2,310.7$ & $2,360.3$ & 22.1 & 0.14 \\
G/F & 0.368 & 0.371 & 0.005 & 0.70 \\
Overall (0 to 16 wk) & & & & \\
ADG (g) & $784.8^{\mathrm{b}}$ & $812.9^{\mathrm{a}}$ & 8.5 & 0.04 \\
ADFI (g) & $2,059.0$ & $2,100.5$ & 14.2 & 0.06 \\
G/F & 0.381 & 0.387 & 0.003 & 0.21 \\
\hline
\end{tabular}

BW, body weight; ADG, average daily gain; ADFI, average daily feed intake; SE, standard error (pooled).

${ }^{1} \mathrm{CON}$, basal diet; T1, basal diet+62.5 ppm microbial feed additive.

${ }^{a, b}$ Means in the same row with different superscripts differ significantly $(\mathrm{p}<0.05)$.

and the pen was used as the experimental unit. The initial BW was used as a covariate for ADG. Before carrying out statistical analysis of the microbial counts, logarithmic conversion of the data was performed. Differences among the treatment means were determined by using the Tukey's test with $p<0.05$ indicating significance.

\section{RESULTS}

\section{Growth performance}

During the weeks 0 to $6, \mathrm{ADG}$ in $\mathrm{T} 1$ treatment was higher $(\mathrm{p}<0.05)$ than CON (Table 2). During the weeks 6 to 16 , no improvement in growth performance parameters were noted. Overall, ADG was improved $(\mathrm{p}<0.05)$ and

Table 3. Effect of Bacillus-based feed additive on the co-efficient of apparent total tract nutrient digestibility in growing-finishing pigs

\begin{tabular}{lcccc}
\hline Item & $\mathrm{CON}^{1}$ & $\mathrm{~T}^{1}$ & $\mathrm{SE}$ & $\mathrm{p}$-value \\
\hline 6 week & & & & \\
Dry matter & $0.760^{\mathrm{b}}$ & $0.790^{\mathrm{a}}$ & 0.008 & 0.03 \\
Nitrogen & $0.757^{\mathrm{b}}$ & $0.789^{\mathrm{a}}$ & 0.009 & 0.04 \\
Energy & 0.763 & 0.781 & 0.011 & 0.26 \\
15 week & & & & \\
Dry matter & $0.743^{\mathrm{b}}$ & $0.778^{\mathrm{a}}$ & 0.009 & 0.02 \\
Nitrogen & 0.743 & 0.767 & 0.010 & 0.13 \\
Energy & 0.753 & 0.773 & 0.008 & 0.10 \\
\hline
\end{tabular}

SE, standard error (pooled).

${ }^{1} \mathrm{CON}$, basal diet; T1, basal diet+62.5 ppm microbial feed additive.

a,b Means in the same row with different superscripts differ significantly $(\mathrm{p}<0.05)$.
Table 4. Effect of Bacillus-based feed additive on the concentration of fecal ammonia gas emission in growing-finishing pigs

\begin{tabular}{ccccc}
\hline Item $(\mathrm{ppm})$ & $\mathrm{CON}^{1}$ & $\mathrm{~T}^{1}$ & $\mathrm{SE}$ & $\mathrm{p}$-value \\
\hline $6 \mathrm{wk}$ & & & & \\
$1 \mathrm{~d}$ & 23.2 & 20.9 & 1.3 & 0.26 \\
$3 \mathrm{~d}$ & 32 & 28.1 & 1.4 & 0.11 \\
$5 \mathrm{~d}$ & $37.2^{\mathrm{a}}$ & $32.4^{\mathrm{b}}$ & 0.9 & 0.01 \\
$7 \mathrm{~d}$ & $43.0^{\mathrm{a}}$ & $37.9^{\mathrm{b}}$ & 1.2 & 0.02 \\
$15 \mathrm{wk}$ & & & & \\
$1 \mathrm{~d}$ & 24.5 & 19.9 & 1.6 & 0.09 \\
$3 \mathrm{~d}$ & $30.5^{\mathrm{a}}$ & $24.9^{\mathrm{b}}$ & 1.3 & 0.03 \\
$5 \mathrm{~d}$ & $41.2^{\mathrm{a}}$ & $33.0^{\mathrm{b}}$ & 1.2 & 0.004 \\
$7 \mathrm{~d}$ & $46.2^{\mathrm{a}}$ & $37.9^{\mathrm{b}}$ & 1.9 & 0.03 \\
\hline
\end{tabular}

SE, standard error (pooled).

${ }^{1} \mathrm{CON}$, basal diet; T1, basal diet+62.5 ppm microbial feed additive.

a,b Means in the same row with different superscripts differ significantly $(\mathrm{p}<0.05)$.

ADFI tended to improve $(p=0.06)$ in $\mathrm{T} 1$ group compared with CON.

\section{Co-efficient of apparent total tract digestibility}

At week 6, CATTD of DM and $\mathrm{N}$ were increased $(\mathrm{p}<0.05)$ in $\mathrm{T} 1$ treatment compared with CON (Table 3). At week 15, pigs feeding on $\mathrm{T} 1$ diet had greater $(\mathrm{p}<0.05)$ CATTD of DM than those feeding on CON diet.

\section{Fecal noxious gas emission}

Supplementation of microbial feed additive decreased $(\mathrm{p}<0.05)$ the level of $\mathrm{NH}_{3}$ emission on $\mathrm{d} 5$ and $\mathrm{d} 7$ at the end of 6th week (Table 4). At the end of 15th week, pigs feeding on the $\mathrm{T} 1$ diet had lower $(\mathrm{p}<0.05)$ fecal $\mathrm{NH}_{3}$ emission at $\mathrm{d} 3$, $\mathrm{d} 5$, and $\mathrm{d} 7$. There were no differences $(\mathrm{p}>0.05)$ in fecal total mercaptans, $\mathrm{H}_{2} \mathrm{~S}$, and VFA concentration between $\mathrm{CON}$ and $\mathrm{T} 1$ (data not shown).

\section{Fecal microbial shedding}

At week 3, the fecal concentrations of Lactobacillus and E. coli were unaffected by dietary treatments (Table 5). At

Table 5. Effect of Bacillus-based feed additive on the fecal microbial shedding in growing-finishing pigs

\begin{tabular}{lcccc}
\hline Item $(\log 10 \mathrm{cfu} / \mathrm{g})$ & $\mathrm{CON}^{1}$ & $\mathrm{~T}^{1}$ & $\mathrm{SE}$ & $\mathrm{p}$-value \\
\hline 3 weeks & & & & \\
$\quad$ Lactobacillus & 7.29 & 7.37 & 0.04 & 0.10 \\
$\quad$ E. coli & 5.94 & 5.78 & 0.07 & 0.14 \\
6 weeks & & & & \\
$\quad$ Lactobacillus & $7.39^{\mathrm{b}}$ & $7.49^{\mathrm{a}}$ & 0.03 & 0.02 \\
$\quad$ E. coli & 5.97 & 5.82 & 0.06 & 0.08 \\
\hline
\end{tabular}

SE, standard error (pooled).

${ }^{1} \mathrm{CON}$, basal diet; T1, basal diet+62.5 ppm microbial feed additive.

a,b Means in the same row with different superscripts differ significantly $(\mathrm{p}<0.05)$. 
week 6, the pigs feeding on diet with Bacillus-based feed additive had a greater $(\mathrm{p}<0.05)$ fecal Lactobacillus counts than the pigs feeding on the CON diet. There was no difference $(\mathrm{p}>0.05)$ in fecal $E$. coli population between the treatments, at week 6 .

\section{Time and water consumption for washing pen}

At the end of the growing phase (week 6) and the finishing phase (week 16), the time and water consumption for washing the pen were decreased $(\mathrm{p}<0.05)$ in $\mathrm{T} 1$ compared to CON (Table 6).

\section{Manure production}

The amount of manure produced by growing pigs per day per head from control group versus treat group was calculated to be $393.5 \mathrm{~g}$ vs $350.3 \mathrm{~g}$ and that by finishing pigs was calculated to be $593.8 \mathrm{~g}$ vs $524.0 \mathrm{~g}$ on dry matter basis. Manure contained $70 \%$ moisture and manure production on wet basis was also calculated. The manure production was reduced by $10.98 \%$ (growing) and $11.76 \%$ (finishing) in treatment group compared with control (Table 7). The concentration of ammonia emission from manure per pig per day was calculated to be $148.0 \mathrm{ppm}$ in control group and $116.1 \mathrm{ppm}$ in feed additive treated groups for growing pigs and $234.9 \mathrm{ppm}$ (control groups) and 168.40 ppm (feed additive treated group) for finishing pigs.

\section{DISCUSSION}

Odorous organic compounds from animal facility are produced due to incomplete anaerobic degradation of manure (Mc Ginn, 2001). The exposure to high level of odorous gases such as ammonia, volatile sulphur, and volatile organic compounds not only has adverse effects on the health and performances of animals, but they also effect on human health and cause environmental problems (Ushida et al., 2003). Therefore, reduction in odorous gas emission through proper manure decomposition plays an important role in reducing environmental pollutants, thereby reducing health hazards and improving growth performances. Zhu (2000) noted that micro-organisms play
Table 6. Effect of Bacillus-based feed additive on the penwashing time and water consumption in growing-finishing pigs

\begin{tabular}{lcccc}
\hline Item & $\mathrm{CON}^{1}$ & $\mathrm{~T}^{1}$ & $\mathrm{SE}$ & $\mathrm{p}$-value \\
\hline Growing phase (wk 6) & & & & \\
$\quad$ Wash time (s/pen) & $631^{\mathrm{a}}$ & $528^{\mathrm{b}}$ & 23 & 0.01 \\
$\quad$ Water consumption (L/pen) & $70.1^{\mathrm{a}}$ & $58.7^{\mathrm{b}}$ & 2.5 & 0.01 \\
Finishing phase (wk 16) & & & & \\
$\quad$ Wash time (s/pen) & $834^{\mathrm{a}}$ & $662^{\mathrm{b}}$ & 35 & 0.01 \\
$\quad$ Water consumption (L/pen) & $92.6^{\mathrm{a}}$ & $73.6^{\mathrm{b}}$ & 3.9 & 0.01 \\
\hline
\end{tabular}

SE, standard error (pooled).

1 CON, basal diet; T1, basal diet+62.5 ppm microbial feed additive.

a,b Mean in the same row with different superscripts differ significant $(\mathrm{p}<0.05)$.

crucial role in production and reduction of mal odors.

In the present study, microbial feed additive containing Bacillus sps was evaluated for its efficacy in reducing mal odor of manure and enhancing productivity in the growing finishing pigs. The inclusion of $62.5 \mathrm{ppm}$ of microbial feed additive in the diet significantly improved ADG at growing phase, but it did not effect on ADFI and G:F ratio. In overall, this feed additive improved on ADG and tended to improve on ADFI. Jonsson and Conway (1992) and Davis et al. (2008) demonstrated that dietary addition of Bacillus spp. led to an increase in the growth performance of pigs. The dietary supplementation of microbial feed additive composed of Bacillus sps improved on the performances (ADG and G/F) of weaning pigs (Wang et al., 2009) and poultry (Zhang et al., 2012; 2013; Zhang and Kim, 2013). However, the results of microbial feed additives supplementation are inconsistent. A previous study by Nitikanchana et al. (2011) reported that the inclusion of Bacillus-based feed additive at the dose rate of 191 million $\mathrm{cfu} / \mathrm{g}$ of feed did not improve the growth performance and carcass characteristics. The differences in the results of these studies can be ascribed to different factors such as diet composition, feed form and their interaction with other dietary additives (Chesson, 1994).

The results of the present study also showed that the CATTD of DM and $\mathrm{N}$ were significantly improved in week

Table 7. Effect of Bacillus-based feed additive on manure production and concentration of ammonia gas in the manure of growing finishing pigs per head per day

\begin{tabular}{|c|c|c|c|c|}
\hline Item & $\mathrm{CON}^{1}$ & $\mathrm{~T} 1^{1}$ & Difference & Reduction $(\%)$ \\
\hline \multicolumn{5}{|l|}{$6 \mathrm{wk}$} \\
\hline Manure (including 70\% moisture, g/pig/d) & $1,311.76$ & $1,167.74$ & 144.02 & 10.98 \\
\hline Average $\mathrm{NH}_{3}$ emission $(\mathrm{ppm} / 300 \mathrm{~g}$ feces/d) & 33.85 & 29.825 & 4.03 & 11.89 \\
\hline Average $\mathrm{NH}_{3}$ emission (ppm/pig/d) & 148.01 & 116.09 & 31.93 & 21.57 \\
\hline \multicolumn{5}{|l|}{16 wk } \\
\hline Manure (including $70 \%$ moisture, g/pig/d) & $1,979.50$ & $1,746.62$ & 232.88 & 11.76 \\
\hline Average $\mathrm{NH}_{3}$ emission $(\mathrm{ppm} / 300 \mathrm{~g}$ feces $/ \mathrm{d})$ & 35.6 & 28.925 & 6.68 & 18.75 \\
\hline Average $\mathrm{NH}_{3}$ emission $(\mathrm{ppm} / \mathrm{pig} / \mathrm{d})$ & 234.90 & 168.40 & 66.50 & 28.31 \\
\hline
\end{tabular}

${ }^{1} \mathrm{CON}$, basal diet; $\mathrm{T} 1$, basal diet+62.5 ppm microbial feed additive. 
6 and DM digestibility was improved in week 15, by dietary supplementation with feed additive containing Bacillus sps. However, digestibility of energy in week 6 and digestibility of $\mathrm{N}$ and energy in week 15 were not impacted by the inclusion of microbial feed additive in the diet. The result for overall improvement in growth performance and digestibility is likely due to the effect of microbial feed additive on intestinal microbial system. Microbial feed additive benefitted the host micro flora through microbial balance in the intestine (Djouzi et al., 1997). Furthermore, the improvement in digestibility could be due to the digestion of non-starch polysaccharides (NSP), which is present in soybean meal, by the enzymes produced by the Bacillus sps contained in feed additive. The insoluble NSP present in soybean meal is degraded by the actions of bacterial enzymes in the colon (Choct et al., 2010).

Han et al. (2001) suggested that microbial feed additive could help in reducing the environmental pollutants, such as fecal odor from animal manure, by improving feed efficiency and nutrient digestibility. Likewise, Ferket et al. (2002) indicated that fecal mal odor and $\mathrm{NH}_{3}$ emission are related to intestinal microbial ecosystem and nutrient utilization. In the present study, $\mathrm{NH}_{3}$ concentration was reduced during both the growing phase and the finishing phase, and other gases such as VFA, total mercaptans, and $\mathrm{H}_{2} \mathrm{~S}$ were not impacted. The observed reduction in $\mathrm{NH}_{3}$ emission in the present study may possibly be due to high nutrient digestibility. In contrast, Wang et al. (2009) did not observe improvement in nutrient digestibility with the inclusion of microbial feed additive in the pigs' diet.

Fecal microbial population was also evaluated in the current study. We observed that Lactobacillus counts were higher in feces of the pigs feeding on the diet with microbial feed additive than those feeding on the control diet, during week 6 . The presence of enzyme and antimicrobial substances produced by the microbial feed additive, in the treatment group compared to control, might explain the improvement in nutrient digestibility and the tendency of decreasing fecal pathogenic bacteria.

In the present experiment, time and water consumption for the clean-up of pens was measured to evaluate the decomposition of manure. Inclusion of microbial feed additive in the diet significantly reduced the demand for water and time in cleaning the pens, both during the end of growing phase and at the end of finishing phase; this indicates that the microorganisms were effective in decomposing manure. This finding is in agreement to that reported by Davis et al. (2008) and Alvaredo et al. (2013), who also reported that including Bacillus sps based feed additive in the diet improved manure decomposition and reduced water consumption for pen cleaning. This is an important impact considering the energy consumption and time for manual labor. The secretion of enzymes such as cellulase, amylase, and protease by the Bacillus strain might explain the effects on manure decomposition (Davis et al., 2008).

In the present experiment the amount of manure produced per head per day by growing and finishing pigs was calculated indirectly based on ADFI and DM digestibility. The manure production was reduced by $10.98 \%$ (growing) and $11.76 \%$ (finishing) in treatment group compared with control. The inclusion of feed additive in the diet also led to reduction in ammonia concentration per pig per day by $21.6 \%$ and $28.3 \%$ from growing and finishing pigs respectively. If 1 million pigs are raised in a farm and fed diet including bacillus-based feed additive, the concentration of ammonia gas emission from manure could be reduced by $32 \mathrm{~kg}$ and $66.5 \mathrm{~kg}$ from growing and finishing pigs respectively. This reduction in ammonia emission would significantly contribute in environment protection by preventing the escape of such gas into the atmosphere.

\section{CONCLUSION}

The results of this study suggest that supplementation with Bacillus sps based feed additive in the diets of growing/finishing pigs significantly improved the body weight gain and in DM and $\mathrm{N}$ digestibility. In addition, there was significant reduction of $\mathrm{NH}_{3}$ emission from the slurry. The reduction of ammonia emission is possibly due to high nutrient digestibility and lower manure production which eventually contribute in the protection of environment. Furthermore, Lactobacillus population was higher in the treatment groups compared to the control. The demand for water and time used in cleaning the pen was significantly reduced with the inclusion of microbial feed additive, which is considered to be economically and environmentally beneficial.

\section{ACKNOWLEDGEMENTS}

This work was supported by the Human Resource Training Program for Regional Innovation and Creativity through the Ministry of Education and National Research Foundation of Korea (NRF-2014H1C1A1067113).

\section{REFERENCES}

AOAC. 1995. Official Method of the Association of Official Analytical Chemists, 16th ed. Washington, DC, USA.

Alvarado, M. A. P., J. C. Lopez, D. B. Varela, G. M. Landin, and J. A. C. Ibarguengoytia. 2013. Benzoic acid and a product based on Bacillus species to protect piglet productivity and the environment. Rev. Mex. Cienc. Pecu. 4:447-468.

Chen, Y. J., B. J. Min, J. H. Cho, O. S. Kwon, K. S. Son, H. J. Kim, and I. H. Kim. 2006. Effects of dietary Bacillus-based 
probiotic on growth performance, nutrients digestibility, blood characteristics and fecal noxious gas content in finishing pigs. Asian Australas. J. Anim. Sci. 19:587-592.

Chesson, A. 1994. Probiotics and other intestinal mediators. In: Principles of Pig Science (Eds. D. J. A. Cole, J. Wiseman, and M. A. Varley). Nottingham University Press, Loughborough, UK. pp. 197-214.

Choct, M., Y. Dersjant-Li, J. McLeish, and M. Peisker. 2010. Soy oligosaccharides and soluble non-starch polysaccharides: A review of digestion, nutritive and anti-nutritive effects in pigs and poultry. Asian Australas. J. Anim. Sci. 23:1386-1398.

Davis, M. E., T. Parrott, D. C. Brown, B. Z. de Rodas, Z. B. Johnson, C. V Maxwell, and T. Rehberger. 2008. Effect of a Bacillus-based direct-fed microbial feed supplement on growth performance and pen cleaning characteristics of growingfinishing pigs. J. Anim. Sci. 86:1459-1467.

Djouzi, Z., C. Andrieux, M. C. Degivry, C. Bouley, and O. Szylit. 1997. The association of yogurt starters with Lactobacillus casei DN 114.001 in fermented milk alters the composition and metabolism of intestinal microflora in germ-free rats and in human flora-associated rats. J. Nutr. 127:2260-2266.

Erwin, E. S., G. T. Marco, and E. M. Emery. 1961. Volatile fatty acid analyses of blood and rumen fluid by gas chromatography. J. Dairy Sci. 44:1768-1771.

Ferket, P. R., E. van Heugten, T. A. T. G van Kempen, and R. Angel. 2002. Nutritional strategies to reduce environmental emissions from non-ruminants. J. Anim. Sci. 80:E168-E182.

Han, I. K., J. H. Lee, X. S. Piao, and D. Li. 2001. Feeding and management system to reduce environmental pollution in swine production - A review. Asian Australas. J. Anim. Sci. 14:432-444.

Hong, H. A., I. H. Duc, and S. M. Cutting. 2005. The use of bacterial spore formers as probiotics. FEMS Microbiol. Rev. 29:813-835.

Hong, J. W., I. H. Kim, O. S. Kwon, J. H. Kim, B. J. Min, and W. B. Lee. 2002. Effects of dietary probiotics supplementation on growth performance and fecal gas emission in nursing and finishing pigs. J. Anim. Sci. Technol. (Kor.) 44:305-314.

Jeong J. S. and I. H. Kim. 2014. Effect of Bacillus subtilis C-3102 as a spores supplementation probiotic feed supplement on growth performance, noxious gas emission, and intestinal microflora in broilers. Poult. Sci. 93:3097-3103.

Jonsson, E. and P. Conway. 1992. Probiotics for pigs. In: Probiotics: The Scientific Basis (Ed. R. Fuller). Chapman and Hall, London, UK. pp. 260-316.

Le D. P., A. J. A. Aarnink, N. W. M. Ogink, P. M. Becker, and M. W. A. Verstegen. 2005. Odour from animal production facilities: its relationship to diet. Nutr. Res. Rev. 18:3-30.

Lei, Y. and I. H Kim. 2014. Effect of Phaffia rhodozyma on performance, nutrient digestibility, blood characteristics, and meat quality in finishing pigs. J. Anim. Sci. 92:171-176.

Meng, Q. W., L. Yan, X. Ao, T. X. Zhou, J. P. Wang, J. H. Lee, and I. H. Kim. 2010. Influence of probiotics in different energy and nutrient density diets on growth performance, nutrient digestibility, meat quality, and blood characteristics in growing-finishing pigs. J. Anim. Sci. 88:3320-3326.

Mc Ginn, S. M. 2001. Odours from intensive livestock operations. Adv. Dairy Technol. 13:417-430.
Nitikanchana, S., S. S. Dritz, M. D. Tokach, R. D. Goodband, J. M. DeRouchey, J. L. Nelssen, and J. R. Bergstrom. 2001. The effects of Micro Source $S$ on growth performance, fecal consistency, and post cleaning microbial load of growingfinishing pigs. Swine day, Report of Progress 1056:240-246.

NRC. 1998. Nutrient Requirements of Swine, 10th ed. Natl. Acad. Press, Washington, DC, USA.

Park, J. H. and I. H. Kim. 2014. Supplemental effect of probiotic Bacillus subtilis B2A on productivity, organ weight, intestinal Salmonella microflora, and breast meat quality of growing broiler chicks. Poult. Sci. 93:2054-2059.

Park, J. H. and I. H. Kim. 2015. The effects of the supplementation of Bacillus subtilis RX7 and B2A strains on the performance, blood profiles, intestinal Salmonella microflora, noxious gas emission, organ weight and breast meat quality of broiler challenged with Salmonella typhimurium. J. Anim. Physiol. Anim. Nutr. 99:326-334.

Schreier, H. J. 1993. Biosynthesis of glutamine and glutamate and the assimilation of ammonia In: Bacillus subtilis and Other Gram-positive Bacteria (Eds A. L. Sonenshein, J. A. Hoch, and R. Losick). Am. Soc. Microbiol. Washington, DC, USA. pp. 281-285.

Schrezenmeir, J., and M. de Vrese. 2001. Probiotics, prebiotics, and symbiotic — approaching a definition. Am. J. Clin. Nutr. 73: 361S-364S.

Sutton, A. L., K. B. Kephart, M. W. A Verstegen, T. T. Canh, and P. J. Hobbs. 1999. Potential for reduction of odorous compounds in swine manure through diet modification. J. Anim. Sci. 77: 430-439.

Ushida, K., K. Hashizume, K. Miyazaki, Y. Kojima, and S. Takakuwa. 2003. Isolation of Bacillus sp. as a volatile sulfurdegrading bacterium and its application to reduce the fecal odor of pig. Asian Australas. J. Anim. Sci. 16:1795-1798.

Wang, Y., J. H. Cho, Y. J. Chen, J. S. Yoo, Y. Huang, H. J. Kim, and I. H. Kim. 2009. The effect of probiotic BioPlus $2 B \AA$ on growth performance, dry matter and nitrogen digestibility and slurry noxious gas emission in growing pigs. Livest. Sci. 120:35-42.

Williams, C. H., D. J. David, and O. Iismaa. 1962. The determination of chromic oxide in faeces samples by atomic absorption spectrophotometry. J. Agric. Sci. 59:381-385.

Zhang, Z. F., and I. H. Kim. 2013. Effects of probiotic supplementation in different energy and nutrient density diets on performance, egg quality, excreta microflora, excreta noxious gas emission, and serum cholesterol concentrations in laying hens. J. Anim. Sci. 91:4781-4787.

Zhang, Z. F., J. H. Cho, and I. H. Kim. 2013. Effects of Bacillus subtilis UBT-MO2 on growth performance, relative immune organ weight, gas concentration in excreta, and intestinal microbial shedding in broiler chickens. Livest. Sci. 155: 343347.

Zhang, Z. F., T. X. Zhou, X. Ao, and I. H. Kim. 2012. Effects of $\beta$ glucan and Bacillus subtilis on growth performance, blood profiles, relative organ weight and meat quality in broilers fed maize-soybean meal based diets. Livest. Sci. 150:419-424.

Zhu, J. 2000. A review of microbiology in swine manure odor control. Agric. Ecosyst. Environ. 78:93-106. 